\title{
SCOPE OF SUPREME COURT REVIEW: THE TERMINIELLO CASE IN FOCUS:
}

THE Supreme Court has long maintained two self-imposed limitations on the scope of its appellate review. First, the Court has traditionally refused to consider issues not raised in the courts below. ${ }^{1}$ Second, it ordinarily refuses to consider issues not properly presented on petition for certiorari, a practice incorporated in Rule 38 of the Rules of the Supreme Court." Both limitations are justified in part by the convenience they afford to the Court itself. By insisting that issues be raised in courts below the Court obtains the benefit of lower court decisions and the research and reasoning on which they were based. Similarly, Rule 38 saves the Court the trouble of searching entire records for issues which are important but well-concealed.

These restrictions serve other ends as well. Insofar as state court judgments are concerned, the policy of refusing to consider issues not raised below tends to promote harmonious relations between state and federal courts. ${ }^{3}$ And Rule 38, by requiring clear presentation of issues for which review is sought, gives to litigants full opportunity to brief and argue any

* Terminiello v. City of Chicago, 337 U.S. 1 (1949).

1. See First National Bank v. Kentucky, 9 Wall. 353, 363 (U.S. 1869); Otis v. Bacon, 7 Cranch 589, 596 (U.S. 1813).

2. See Revised Rules of the Supreme Court, 305 U.S. 685 (1939), as amended, 335 U.S. 915 (1948). Rule 38 (governing review on writ of certiorari of decisions of state courts, circuit courts of appeals and the United States Court of Appeals for the District of Columbia) par. 3: "The petition shall contain a summary and short statement of the matter involved; a statement particularly disclosing the basis upon which it is contended that this Court has jurisdiction to review the judgment or decree in question; . . . the questions presented; and the reasons relied on for the allowance of the writ. Only the questions specifically brought forward by the petition for writ of certionari vill be considered." See Dickinson Industrial Site, Inc. v. Cowan, 309 U.S. 382, 389 (1940) ; General Talking Pictures Corp. v. Western Electric Co., 304 U.S. 175, 178, 179 (1938) (Court will consider only questions raised in the petition, not those raised in supporting brief).

3. This policy had an early historical importance. Section 25 of the original Judiciary Act of 1789 gave the Supreme Court power to review state court decisions involving federal matters. But the validity of this grant was vigorously challenged by the states, some of whom thought that there was no constitutional warrant for any revicw by the United States Supreme Court of state court decisions. MFoore, Cossusirssry o: THE JUdicLAL CODE 565 (1949). The power of review was upheld in Afartin v. Hunter's Lessee, 1 Wheat. 304 (U.S. 1816), and eventually the furor quieted down. Mleanwhile, however, the Supreme Court found it politic to keep its review of state court judgments narrowly confined, and this policy, once started, carried on by its own momentum long after the historical context in which it was born had changed. It would seem, therefore, that there is no longer such necessity for deference to state courts as to require the Supreme Court to follow its traditional practice in all cases. Tradition is a poor defense for a decision contrary to the demands of justice.

For further discussion of the scope of Supreme Court jurisdiction to reviev state decisions, see MOORE, op. cit. stupra, at 565-78. 
issue which might serve as the basis for disposition of their case. ${ }^{4}$. The rule therefore promotes the interests not of the courts alone but of the litigants for whose benefit the courts sit.

But strict adherence to these limitations on the scope of review may lead to obvious injustice. Hence the Court has never considered them absolutely binding. Where there has been "fundamental error" clearly determinative of the case, the Supreme Court will consider the issue even though it was not raised below. ${ }^{5}$ or properly presented in the petition for writ of certiorari. ${ }^{6}$ Where strict application of the doctrines would frustrate the obvious intent of the parties, ? or where the decision of a state court necessarily in-

4. In Flournoy v. Wiener, 321 U.S. 253, 259 (1944), the Court said, "It is a fitmiliar rule, consistently followed, that upon appeal from a state court this Court will not pass upon or consider federal questions not assigned as error or designated in tho points to be relied upon even though properly presented to and passed upon by the state court. [citing cases]. The rule is the same in the case of applications for certiorari. Rule 38, p. 2; [citing cases]." And again, at 261, the Court said, "But this question is not before us because appellant, by his statement of points to be relied upon, has affirmatively excluded it from consideration on this appeal. . . . In any case wa ought not consider it here because in reliance upon this declaration neither party has bricfed or argued it in this Court. Rule 27, par. 6 declares that errors not urged in the briefs will be disregarded. Antd, independently of 'technical' rules it is not the habit of this Court to decide important constitutional questions which the parties have not presented, briefed or argued."

In a lengthy dissent, Justice Frankfurter argued that the federal question had been adjudicated by the Supreme Court of Louisiana and was properly before the Supreme Court of the United States, "unless the duties of this Court . . . hang on the thread of mere verbalism." Id. at 264 . He concluded: "We ought not to create a constitutional grievance which the parties themselves have never entertained in order to avoid adjudjcation of the only question which has been in the case from the beginning." Id. at 275 .

5. Rule 27, par. 6, provides: "When there is no assignment of errors, counsel will not be heard, except at the request of the Court; and errors not specificd according to this rule will be disregarded, save as the Court at its option may notice a plain crror not assigned or specified." (Emphasis added). See also Rules of the Supreme Court 9 and 13, par. 9. Analogous provisions are contained in the Federal Rules of Criminal Procedure and Federal Rules of Civil Procedure. See Sibbach v. Wilson \& Cn., 312 U.S. 1 (1941) (where a Rule of Civil Procedure specifically exempted from punishment for contempt the refusal to obey an order to submit to physical or mental examination, although action of lower courts in treating it as such was not assigned as error in Circuit Court of Appeals, the error is of such a fundamental nature that the Court must notice it); Mahler v. Eby, 264 U.S. 32 (1924) (that warrant lacks finding requircd by statute is such a plain and fundamental error that Court will notice it, although not included in assignment of errors).

6. Sibbach v. Wilson \& Co., 312 U.S. 1 (1941); see Bryant v. Zimmerman, 278 U.S. 63, 64, 65 (1928).

7. See Flournoy v. Wiener, 321 U.S. 253, 273, 274 (1944) (dissenting opinion); Bryant v. Zimmerman, 278 U.S. 63, 64 (1928) (if the record as a whole shows eithor expressly or by clear intendment that the validity of a state statute was in question, the claim of invalidity will be regarded as having been adequately presented). 
volved determination of a federal question, ${ }^{8}$ the Court has set the doctrines aside. And occasionally the Court has disregarded obvious technical imperfections such as failure to state that the federal Constitution was involved.'

In the much publicized case of Terminiello v. City of Chicago ${ }^{13}$ the Supreme Court again departed from these two long-standing practices and ruled on a substantive constitutional issue which neither party had raised or argued at any time. Newspapers and legal periodicals, in discussing the case, have concentrated on the substantive issues of free speech. ${ }^{11}$ Almost overlooked in this battle of words has been the procedural aberration which made the decision possible.

Arthur Terminiello was found guilty, in the Municipal Court of Chicago, of violating a city ordinance ${ }^{12}$ by giving a speech which tended to a breach of the peace. The judgment of conviction was affirmed by the Appellate Court for the First District, ${ }^{13}$ and by the Supreme Court of Illinois. ${ }^{14} \mathrm{Re}-$ viewing the case on certiorari, the United States Supreme Court reversed the judgment of the courts of Illinois on the ground that the trial judge, in his charge to the jury, so broadly construed the ordinance under which petitioner was convicted as to make it unconstitutional. ${ }^{15} Y^{\prime}$ et no exception

8. See Sayward v. Denny, 158 U.S. 180, 184 (1S94) (where it appears by clear and necessary intendment that a federal question was directly involved so that the state court could not have given judgment without deciding it, the Supreme Court has jurisdiction); Bell's Gap R.R. v. Pennsylvania, 134 U.S. 232 (18S9) (if decision of a federal question is necessarily involved in the judgment rendered, it is immaterial that the state court avoided all reference to the question).

9. In Bryant v. Zimmerman, 278 U.S. 63,67 (192S), the petition for writ of habeas corpus (denied by the state courts), although asserting that the state statute under which petitioner was being held was "unconstitutional," failed to specify any constitutional provision, federal or state, involved. The Court said: "No particular form of words or phrases is essential, but only that the claim of invalidity and the ground therefor be brought to the attention of the state court with fair precision and in due time." See Flournoy v. Wiener, 321 U.S. 253, 273, 274 (1944) (dissenting opinion). But cf. Seaboard Air Line Ry. v. Watson, 287 U.S. 86, 91 (1932).

10. Terminiello v. City of Chicago, 337 U.S. 1 (1949).

11. Rosenwein, The Supreme Court and Freedom of Specch-Tcrminicllo v. City of Chicago, 9 LAw. Gumb Rev. 70 (1949) ; Notes, 29 B.U.L. REv. 556 (1949); 18 Fo.d. L. REv. 283 (1949) ; 38 GEo. L. J. 94 (1949); 24 N.Y.U.L.Q. REv. \&85 (1949); 25 NOTRE Daxre Law. 99 (1949).

12. "All persons who shall make, aid, countenance, or assist in malking any improper noise, riot, disturbance, breach of the peace, or diversion tending to a breach of the peace, within the limits of the city ... shall be deemed guilty of disorderly conduct, and upon conviction thereof, shall be severally fined not less than one dollar nor more than two hundred dollars for each offense." CITY of Cmicngo REv. Cone c. 1, §1 (1) (1939).

13. 332 IIl. App. 17, 74 N.E.2d 45 (1st Dist. 1947).

14. 400 III. 23, 79 N.E.2d 39 (1948).

15. Justice Douglas objected to the following portion of the jury charge: "The court instructs the jury that breach of the peace consists of any misbehavior which violates the public peace and decorum. The misbehavior may constitute a breach of the peace 
to the particular jury charge had been taken by the petitioner; ${ }^{16}$ the issue had not been raised before the Illinois appellate courts; nor had it appeared in the petition for writ of certiorari as a "question presented" or "point to be relied upon," 17 as required by Rule 38 of the Supreme Court Rules. ${ }^{18}$

if it stirs the public to anger, invites dispute, brings about a condition of unrest, or crcates a disturbance, or if it molests the inkabitants in the exjoyment of peace and quict by arousing alarm. ..." (emphasis added). Transcript of Record, p. 129, Terminiello v. City of Chicago, 337 U.S. 1 (1949). The words admittedly used by the petitioner (e.g., "scum" and "slimy scum," directed to members of the audience) were such as to provoke such comments from the audience as "kill the Jews," "get rid of Jews, niggers and Catholics," "cripple them," "sterilize them." Undeniably, a disturbance was created by the use of these words, and thus if the other, objectionable phrases of the jury charge were deleted, the ordinance might, as construed, meet the test of constitutionality as c5tablished by the Chaplinsky case. Chaplinsky v. New Hampshire, 315 U.S. 568 (1942). Justice Vinson's separate dissent implicitly raises the question as to whether petitioner was harmed by the erroneous jury charge, inasmuch as the appellate courts of Illinois affirmed the conviction because they thought that the jury had found Terminiello's words to be "fighting words" within the meaning of the Chaplinsky decision. 332 IIl. App. 1\%, $23,38,74$ N.E.2d 45, 48, 54; 400 III. 23, 33, 79 N.E.2d 39, 45. It is this question which Justice Douglas agreed in his opening statement was brought before the Supreme Court for determination, although not decided in the majority opinion.

16. Rule 62 of the Municipal Court of Chicago relating to instructing the jury specifically provides that "(3) Objections to the charge must be made before the jury retire and out of the presence of the jury. They must specifically point out wherein the part objected to is erroneous and the party objecting must indicate clearly the correction therein desired to be made, and upon the objections being made the judge may make such corrections as he may deem proper."

The requirement that exceptions must be specific is contained in Supreme Court holdings as well as in Rule 62, strpra. See e.g., Palmer v. Hoffman, 318 U.S. 109, 119 (1943) ; Seaboard Air Line Ry. v. Watson, 287 U.S. 86, 91 (1932) (assignment as error court's failure properly to instruct jury is too vague and indefinite to permit consideration); McDermott v. Severe, 202 U.S. 600, 610 (1910) ("It has been too frequently held to require the extended citation of cases that an exception of this general character will not cover specific objections, which in fairness to the court ought to have been called to its attention in order that if necessary, it could correct or modify them"). Counsel for Terminiello did object to plaintiff's requested instructions, the substance of which the court subsequently incorporated in part into the charge to the jury, not on the ground that it contravened the constitution but simply that "This is not the law, consequently it does not fit the facts." [sic] Transcript of Record, p. 128, Terminiello v. City of Chicago, 337 U.S. 1 (1949).

17. Only a most patient analysis of the lengthy and confused record of the case reveals the intention of Terminiello with respect to the debatable issue. He mentions tho construction of the ordinance in the purely rhetorical "question presented," but did not attack it as such, and his reasons relied on for allowance of the writ were (1) that the judgments of the lower courts were repugnant to prior decisions of the Supreme Court; (2) that his conviction would constitute a "previous restraint" upon the right of the citizens of Chicago to speak and assemble freely; and (3) that there was no breach of the peace. Petition for a Writ of Certiorari, p. 9, Terminiello v. City of Chicago, 337 U.S. 1 (1949).

18. Justice Frankfurter, dissenting, pointed out that the ground for reversal was explicitly disclaimed on behalf of Terminiello at the bar of Court. He vigorously ob- 
In thus disregarding its traditional rules, the Court may have felt that the parties actually intended to put the issue before both the Illinois courts and the Supreme Court. ${ }^{19}$ Although Terminiello did not dispute the constitutionality of the ordinance "on its face" or as construed in the judge's charge, ${ }^{20}$ he clearly maintained throughout that a conviction under this

jected to the fact that the majority saw fit "to inject an error into the record in order to avoid the issue on which the case was brought... for certainly relief from the payment of a fine of $\$ 100$ could not alone have induced this Court to excogitate a defect in the judgment which counsel thoughtfully rejected and which three State courts did not consider. ..." 337 U.S. 1, 12. See Whitney v. California, 274 U.S. 357, 362, 363 (1927) (the presence of one properly presented question does not authorize the Court to search the record for others not so presented). Justice Vinson dissented on the ground that the Illinois courts had never considered, and therefore could not be thought to have affirmed, the construction placed upon the ordinance. Terminiello v. City of Chicago, supra, at 7. A federal claim "must" have been denied, or a state statute upheld, by the highest court of the state in order for the Supreme Court to have jurisdiction on certiorari or appeal. 28 U.S.C. $\$ 1257$ (1948). See CIO v. AfcAdory, 325 U.S. 472, 477 (1944).

19. Terminiello v. City of Chicago, 337 U.S. 1, 6 (1949). "Petitioner raised both points-that his speech was protected by the Constitution; that the inclusion of his speech within the ordinance was a violation of the Constitution. ... The record malkes clear that petitioner at all times challenged the constitutionality of the ordinance as construed and applied to him."

20. The Court, citing Winters v. New York, 333 U.S. 507, pointed out that the construction by the highest state court was binding on the Supreme Court. The Winters case dealt with a New York statute banning obscene publications. Petitioner challenged the statute as unconstitutional on its face for being "obscure and indefinite." By failing to take exception to the jury charge, however, he failed to challenge the clarification by means of which the lower court attempted to preserve the constitutionality of the ordinance. The Supreme Court, finding the law invalid on its face, considered only the question of whether as construed it might be clear enough to pass the test of constitutionality. On this basis the statute was invalidated. In so doing, it ruled that the interpretation of a statute by a court "puts these words [of interpretation] in the statute as clearly as if it had been so amended by the legislature" Id. at 514. Had Terminiello ever challenged the constitutionality of the municipal ordinance on its face, the Winters case might have been a proper precedent for the Court to reverse the state court because of the construction of that ordinance.

The Court also cited Stromberg v. California, 283 U.S. 359, in defense of its disregard of Terminiello's failure to take proper exception to the jury charge. In the Stromberg case petitioner challenged the validity of the statute on its face, but did not take exception to the instructions to the jury. The Supreme Court nonetheless considered the trial court's charge which, stated in the disjunctive, permitted conviction on any one of three grounds. Finding one of these grounds unconstitutional, the decision was reversed; for it was "impossible to say under which clause of the statute the conviction was obtained" (Id. at 368). The Stromberg case is no square precedent for the Court's interference in the Terminiello case, even though, as the Court noted, the charge to the jury in the Terminiello case was also stated in the disjunctive In the Stromberg case the Court held that "an attack on the statute as a whole was equally an attack on each of its individual parts." But Terminiello attacked the Chicago ordinance neither "as a whole" nor as to any of its parts. 
ordinance would be an unconstitutional abridgement of his rights under the First and Fourteenth Amendments. ${ }^{21}$ The.Court may have concluded that since the appellant was challenging the application of the ordinance, he was also challenging the trial judge's construction on which the application was based. In a sense, this was true. In denying that the ordinance should be applied to him at all, Terminiello was contending that no construction could be valid.unless it yielded a directed verdict ${ }^{22}$ or binding instructions to the jury for acquittal, ${ }^{23}$ a construction which he did not get.

But the Court's conclusion; if 'such it was, erased a distinction between two substantially different levels of constitutional attack, each of which necessitates a different kind of rebuttal argument by those defending a conviction. It is one thing to maintain, as Terminiello clearly did, that a statute cannot under any construction be constitutionally applied to a particular set of facts. It is quite another to claim that even though the statute, if construed in certain ways, could be applied to those facts, the actual construction given in the charge to the jury was so broad as to violate the Fourteenth Amendment. This claim Terminiello did not make, and the record indicates that his failure was due not to a technical oversight but to a specific intention not to make it. ${ }^{24}$ Since counsel for the city of Chicago was thus pre-

21. Transcript of Record, pp. 55, 84, 126, Terminiello v. City of Chicago, 337 U.S. 1 (1949).

22. Transcript of Record, p. 84, Terminiello v. City of Chicago, 337 U.S. 1 (1949). On the motion for directed verdict, Terminiello argued that "[t] he basis is the first amendment to the United States Constitution; Father Terminiello had a right to say what he said and what he said was protected by the first amendment to the Constitution, that the charge in this case, namely, a diversion tending to a breach of the peace, if it is constitutional under the first amendment, could not prohibit free speech or tend to prohibit free speech, otherwise it would be unçonstitutional." He was here challenging a construction yet to be placed upon the ordinance by the court, in saying that the ordinance, no matter how construed, "could not prohibit free speech or tend to prohibit frec speech." Similarly, he said that "to charge this defendant with committing a misdemeanor because he gave the speech in question is a contravention of the first amendment to the constitution," (emphasis added) . The trial judge, in overruling these motions, did not consent to this construction of the ordinance. He said nothing, however, regarding the proper construction until he charged the jury.

23. At the end of the trial; Terminiello's counsel was apparently willing to concede that the ordinance might be construed constitutionally. Although his requested instruc, tions were concerned largely with the proper legal definition of a "public meeting place," he also asked that the jury be instructed that "no danger flowing from speech can be deemed clear and present unless the incidence of the evil apprehended is so imminent that it may befall before there is opportunity for discussion." Transcript of Record, pp. 126-7, Terminiello v. City of Chicago, 337 U.S. 1 (1949).

24. Terminiello throughout insisted that the ordinance no matter how construed could not constitutionally be applied to his speech. See Transcript of Record, pp. 55, 84, 126. With the exception of the instructions which he requested be given the jury (see note 23 stpra) he nowhere conceded that the ordinance might, properly construed, apply to him. His failure to object to the jury charge given, his failure to raise the issue in the appelate courts of Illinois, and his explicit denial at the bar of the Su. 
cluded at all times from arguing the point, the Court in deciding the case on an issue not raised was neglecting the policy of fairness to litigants which underlies Rule 38.

But the Court's decision to overlook Rule $3 \mathrm{~S}$ probably was not based on reflections concerning Terminiello's intentions. It is more likely that the Court was motivated by an understandable and entirely justifiable desire not only to reach what it considered to be a correct result in this case, but also to prevent future convictions under a too-broadly construed ordinance. ${ }^{25}$ There is no irreconcilable conflict, however, between the policy underlying Rule 38 and the desire to determine substantive constitutional issues. The Court could have resolved the dilemma by granting the city of Chicago's petition for rehearing.s The litigants would thus have been afforded adequate opportunity to brief and argue the issue which the Court considered "dispositive of the case." This is a right to which they should be entitled, even though in this particular case, where the trial judge's charge seemed undeniably defective, the granting of the petition might have made no difference in the ultimate result. Another alternative would have been to remand the case to the Illinois Supreme Court for a specific ruling on the appropriateness of the trial judge's construction of the ordinance. ${ }^{.7}$ This

preme Court that the trial court's erroneous construction of the ordinance was the basis upon which he sought reversal, indicate that he intentionally distinguished "applieation" from "construction." Cf. Johnson v. United States, 318 U.S. 169, 200, 201 (1943) (where defense counsel waived his objection to prosecutor's comment by failing to take exception to the jury charge, and when that objection did not appear in the motion for new trial or assignment of error, the waiver will not be considered mere inadvertency or oversight).

That the record in the Terminiello case contains innumerable ambiguities is a fact which cannot be overemphasized. Counsel for Terminiello in his motion for judgment notwithstanding the verdict or for new trial (Transcript of Record, p. 55) made vague references to the instructions given the jury: "The court improperly gave to the jury the instructions objected to by the defendant." But he failed to malee any objection whatsoever to the jury charge. "The court erred in refusing to give certain instructions requested by the defendant." But what certain instructions the court erred in omitting are not indicated. See note 16 stpra. Under Inlinois practice, it is mandatory for an appellant to set forth all of the instructions for the plaintiff and the defendant in order to obtain a review based on an instruction. It is clear from the Transcript of the Reeord that Terminiello's counsel omitted some of the court's instructions. Inasmuch as he thus violated state practice, and the Supreme Court is bound by the law of Illinois, it is arguable whether even had an objection been seasonably made the Supreme Court could have considered this objection.

25. The expedient of granting a rehearing in appropriate cases would be a desirable departure from the usual practice of refusing to consider issues raised neither in the courts below nor on appeal. If strictly adhered to, these limitations might easily become in other cases distressing barriers to legitimate but inexpertly pleaded claims of unsophisticated litigants.

26. The Petition for Rehearing was denied, June 13, 1949. 337 U.S. 934 (1949).

27. This alternative is probably more appropriate to cases where the state court's decision has been incomplete or ambiguous. Cole v. Arkansas, 333 U.S. 196 (1948) 